The $5^{\text {th }}$ International Conference on Family Business and Entrepreneurship

\title{
FACTORS AFFECTING SAVING BEHAVIOUR AMONG ONLINE GAMERS IN GREATER JAKARTA
}

\author{
Farida Komalasari ${ }^{1 *}$, Dio Julio Sander ${ }^{2}$, Adhi Setyo Santoso ${ }^{3}$, Lukas Sangka \\ Pamungkas ${ }^{4}$ \\ ${ }^{1}$ Faculty of Business, President University, \\ Corresponding author: farida_k@president.ac.id,
}

\begin{abstract}
:
Games, especially digital online games in both PC and mobile phones are in its peak of developing and growing. Along with that, the number of gamers significantly increased from every range of age for both men and women. In 2017, the number of gamers in Indonesia are 43.7million people, which increased to 52 million people in 2019. Contradicting the growth of gamers, Indonesians' intention to save is low compared to other countries in ASEAN. Considering this phenomena, this paper aims to investigate the factors that affects saving behaviour of online gamers in Indonesia, especially in Greater Jakarta. This is a quantitative research using primary data from 218 respondents. The respondents are selected using non-probability sampling that are purposive sampling and snowball sampling. The data were gathered using questionnaire, whuch consists of demographic variables and 41 statements as variable measurements distributed to online gamers in Greater Jakarta, Indonesia. The data were analyzed using Structural Equation Model (SEM). A research found that financial literacy significantly influences both financial attitude and saving behaviour of online gamers in Greater Jakarta, Indonesia. The financial attitude also significantly influences their saving behaviour. Meanwhile, family influence and peer influence do not significantly influence their saving behaviour. Authors believe that this is the first research in Indonesia using this framework with online gamers as its object of research.
\end{abstract}

Keywords: family and peer influences; financial literacy; financial attitude; saving behaviour; online gamers in Greater Jakarta-Indonesia

\section{Introduction}

Saving means that it is the act of minimizing the spending of one's income. The remaining of spent income that are not spent is called savings (Achar, 2012). People leave some of their income as insurance for unexpected incidents or unwanted case and as an investment to ensure that they have the sufficient resources, which fund is used to support their future (Putri, 2017). One of the main reasons to save is to anticipate the increasing price in the future (Gloria, 2017). Indonesia is the world's top 5 nation with the largest population with 272 million people as of June 2021 (dukcapil.kemendagri.go.id, 2021) which is also known as one of the world's most consumptive nation (Oktavira, 2016). This fact shows that saving is indeed a must for Indonesians.

On the other side, the number of online gamers in Indonesia increased significantly in the period of 2017 to 2019. In 2017, the number of gamers in Indonesia are 43.7million, which then increased to 52 million in 2019 (Fauzy, 2020). Out of the total online gamers in Indonesia, 47\% of them are in the age of 21-35 years 307 
old which are actually in the range of age where people are trying to work as hard as possible to earn and save money. Online game has spread out like virus that is played by people regardless of their age and gender. Indonesian gamers are in the second rank in Southeast Asia in terms of playing using both PC/laptops and mobile phones (46\%) below Vietnam (61\%) (NewZoo, 2017). To support the online gamers, many gaming cafes are opened and developed in Greater Jakarta (CNN Indonesia, 2021).

According to Latifa (2017), playing online games may result in decreasing one's performance, wasting their time, increase the possibility of having a disease, wasting their money, and indirectly develop an extravagant habit. An interview in 2016 made students admitted that they spent more than 600 thousand rupiah a month for playing online games while their friends would go to an internet café for playing online games after school in the afternoon (Prakasa, 2016).

Meanwhile in 2016, Otoritas Jasa Keuangan (OJK) encouraged people to save money. OJK conducted a seminar and saving campaign to boost people's interest and awareness towards saving while also socialized about financial instruments. OJK released some new products of saving to increase financial inclusiveness such as student saving, non-office financial service, multi funds, and micro-finance (Nisaputra, 2016). Then, OJK mentioned that Indonesian citizens are still not familiar with saving. The data shows that only 19\% of the total citizens in Indonesia above the age of 15 have a bank account (Dwiantika, 2016). How about the saving behaviour of online gamers in Indonesia, especially in Greater Jakarta?

Thus, to know the saving behaviour of online gamers in Greater Jakarta is needed. Therefore, this research aims to investigate the factors affecting the saving behaviour of online gamers in Greater Jakarta, Indonesia. There are many factors of saving behaviours, such as parents education (Firmansyah, 2014), peer pressure or people around (Alwi, Hashim, \& Ali, 2015), financial literacy \& financial knowledge (Jamal, Ramlan, Karim, Moohidin, \& Osman, 2015), and possible risk in life (Kapounek, Korab, \& Deltuvaite, 2015). Alwi, et.al (2015) also mentioned that peer pressure influenced one's attitude. This research focuses on 4 factors, which are family influence, peer influence, financial literacy, and financial attitude. This is the first research using these 4 factors to investigate the saving behaviour of online gamers in Greater Jakarta, Indonesia.

\section{Literature Review}

\section{Saving Behaviour}

According to Subhamv and Priya (2016), saving contains various explanations and wide meaning; they explained that saving could be defined from an aeconomic and psychological term. In an economic term, saving means the remaining income of a person after it is deducted by consumption in a certain period of time. In psychological term, saving means that it is the process of not using money for a specific period of time. As a conclusion, saving behaviour is a set of conceptions of future needs, saving decision, and saving action.

Firmansyah (2014) mentioned that the factor that affects saving behaviour is parents' education. He stressed that the children's biggest foundation is family education. However, other researchers mentioned another variable that affects saving behaviour which is peer influence. They stated that one's attitude is easily influenced by peer pressure when it comes to decision making (Alwi, et. al., 2015). In addition, a research in Canada found that one's decisions on saving and spending greatly depends on the people around them (Alwi, et. al., 2015). According to Jamal, et. al.,(2015), being financial literate would improve one's financial outcomes (saving or investment). In addition, they added that having financial knowledge would trigger a positive attitude that will lead to a better behaviour such as making smart financial decisions. Lastly, the measurement of saving behaviour is the reaction or response of one's facing the possible risk in life (Kapounek, et. al., 2015).

\section{Financial Attitude}

Financial attitude is defined as a situation, idea, and judgment about finance (Herdjiono \& Damanik, 2016). According to Potrich, Vieirera, Mendes-Da-Silva (2016), it is defined as a set of feeling, information and conceptions about learning which results in the preparedness to respond favourably.

Attitudes are shaped by the environmental interaction such as family, friends, school, country, media, and any other shapes of interaction (Jorgensen, 2007). Jamal, et. al. (2015) stated that being knowledgeable 
about financial will trigger one's attitude to have a positive financial behaviour. Moreover, Jorgensen (2007) and Jamal, et. al. (2015) stated that financial knowledge and financial attitudes have been proven to have a significant influence toward financial attitude. Another literature stated that the contribution of parents in delivering financial education while also being the role model is essential to encourage positive financial attitudes and behaviour (Shim, Barber, Card, Xiao, \& Serido, 2010). Therefore, the factors that affect financial attitude is financial knowledge.

Herdjiono \& Damanik (2016) stated that there is a relation of financial attitudes and level of financial problem. Thus, the level of financial attitudes is shown by how one faces their financial issues. They also mentioned that the financial behaviour is developed from financial attitudes. Then, thoughtless people would likely have a bad financial behaviour when facing financial problems. In conclusion, financial attitude is measured by how people treat and face financial issues.

\section{Family Influence}

Family can be described as a nuclear family and extended family. Nuclear family is often referred to a husband and wife and their children. Meanwhile, an extended family is defined as the "interactive and mutually supportive individuals consist of kin and non-kin members of different generations that live together in the same household or related households in a different location" (Lien, Westberg, Stavros, \& Robinson, 2017). However, Firmansyah (2014) defined a family as the first environment of every human being and also the first teacher of them.

Children keep their families or parents' teaching the most in their mind because parents provide them with the very basic knowledge (Williams, 2010). The children follow parents as their guidance from the first time they were born until they leave home. In addition, Choi (2016) found that parents from different socioeconomic backgrounds support activities that can help children to develop. It indicates that parents would encourage their children to develop themselves even after their family give the basic education. Choi (2016) and Williams (2010) showed that parents' methods of teaching and communication are the factors that affect how well is the influence of the family.

Jamal, et. al. (2015) stated that they acknowledged parents' role as the key to the children's financial socialization. Parents influence the children's financial behaviour development greatly; they become the role model for their children in managing their financial affairs. Likewise, Williams (2010) mentioned that from the moment the children were born until they leave the household, they learn and look up to their parents as a guidance and teacher. Therefore, children imitate and follow parental figures. In addition to Williams (2010) and Jamal, et. al.(2015), Thung, Kai, Nie, Chiun, \& Tsen (2012) mentioned that family influence is measured by how well the saving behaviour of the children is.

\section{Peer Influence}

According to Cambridge Dictionary (2017), peer means one who is in the same age or has the same social degree as the other people in the group. Based on Jamal, et. al.(2015), peer influence could be defined as the power of a group or individual with same age or the same social degree to change the behaviour of others (individual or group).

According to Alwi, et. al.(2015), young people are easily influenced by peers. Thung, et. al.(2012), his literature stated that the behaviour of one could be different depends on the society or group of people one meets. Moreover, they find that one as a member of a group would likely have the similar environment that will influence their behaviour. Jamal, et. al. (2015) mentioned a similar statement that people with similar preferences would tend to be in a same group that in the end will create a relation between group and one's behaviour.

Alwi, et. al. (2015) stated that closer peers proven to have significant influence on one's attitude or behaviour in both social and physical distance. Thung, et. al. (2012) found that there is a weak relation between peer influence and retirement saving behaviour. Meanwhile, Jamal, et. al. (2015) mentioned that peer influence has an important part in encouraging retirement savings decision. In conclusion, peer 
influence could be measured by the changes in one's behaviour, attitude, habits, or decisions affected by interactions with peers.

\section{Financial Literacy}

Financial literacy is different with financial education or financial knowledge even though it is often been used as synonyms. The three are conceptually different; financial literacy has a deeper concept compared to the rest (Potrich, et. al., 2016). Financial literacy could be defined as one's ability to use their understanding about how finance work to make an effective and informed financial decision (Dolphin, 2012). Potrich, et. al. (2016) stated that one could have financial knowledge, but to be categorized as financial literate, one should have the ability on applying it while making a decision. They stated that only having financial knowledge is not enough to be able to manage finance effectively. Having financial information doesn't guarantee someone will be able to manage finance well.

Eniola \& Entebang (2017) showed the effect of business owner-manager's financial knowledge, financial awareness, and financial attitude in converting financial literacy to companies' performance. They confirmed that financial knowledge and awareness of SME business owners-managers are obviously not a prerequisite for the performance of SMEs. According to Tuffour, Amoako, \& Amartey (2020), the results revealed a significant effect of financial literacy on a firm's performance (both financial and non-financial performance). Also, all the three components of financial literacy (awareness, attitude, and knowledge) have a significant positive effect on both financial and non-financial performance.

Alwi, et. al. (2015) found that the majority of business students have more knowledge compared to nonbusiness students. Meanwhile, Jorgensen (2007) found that business students are more knowledgeable compared to non-business students in terms of investments. It also applies to married and unmarried people, whereas married people show more knowledge of financial compared to unmarried people. He also showed that financial course is essential to be financial literate. Jamal, et. al. (2015) also stated that without a sufficient financial knowledge, one would make a more incorrect financial decision. Therefore, the factor of financial literacy is the level of education.

According to Jorgensen (2007), financial literacy has two measurements which are understanding and application. Understanding means the level of financial knowledge, while application refers to how well one could manage one's personal financial.

\section{Theoretical Framework and Hypothesis}

The framework of this research is developed based on the theory of planned behaviour (Jamal, et. al.(2015). There are three independent variables, one mediating variable, and one dependent variable. The independent variables are family influence, peer influence, and financial literacy. The mediating and dependent variables are financial attitude and saving behaviour, respectively.

The hypotheses are as follows:

H1: Family influence influences saving behaviour.

H2: Peer influence influences saving behaviour.

H3: Financial literacy influences saving behaviour

H4: Financial literacy influences financial attitude.

H5: Financial attitude influences saving behaviour.

\section{Research Gap}

Comparing to the four previous researches, this research has different variables and unit analysis. Thung, et. al. (2012) investigated the determinant factors of saving behaviour but excluded the financial attitude as the mediating variable between financial literacy and saving behaviour. Shim, et. al. (2010) and Jorgensen (2007) have the similar object of study which are young people. Meanwhile, Alwi, et. al., 2015 conducted a research on college students. This research focused on the online gamers in Greater Jakarta, 
Indonesia. Thus, this research has two gaps, which are theoretical gap, compared to Thung, et. al. (2012) and empirical gap, compared to Shim, et. al. (2010), Jorgensen (2007), and Alwi, et. al. (2015).

\section{Research Method}

\section{Sampling Design}

This is quantitative research using primary data. The data were gathered by using a questionnaire with 41 measurement statements. The population are online gamers in Greater Jakarta, Indonesia. According to Ferdinand (2004), the minimum representative respondents are the amount of indicators times 5. Therefore, the number of respondents is 205 , calculated from 41 measurement statements times 5 . By the end of data gathering, this research has gathered 218 valid respondents, which have fulfilled the minimum required number of samples. The samples were chosen using a non-probability sampling, which was a purposive sampling and snowball sampling.

\section{Data Analysis Method}

The data analysis consists of two, which are descriptive analysis and inferential analysis. Percentage analysis is implemented in the descriptive analysis, while Structural Equation Model (SEM) is used in inferential analysis. SEM consists of the goodness of fit test and hypothesis test. Before inplementing the goodness of fit test and hypothesis test; normality, validity and reliability test were implemented. Based on Hair Jr, Black, Babin, and Anderson (2010), the criteria used to determine the goodnes of fit of the model are the Normed Fit Index (NFI; >=0.9), Tucker Lewis Index (TLI; >0.95), Comparative Fit Index (CFI; $>0.9$ ) and Root Mean Square Error of Approximation (RMSEA; 0.05<RMSEA $<0.08$ ). The criteria used to accept the hypothesis is p-value $(<0.05)$ and Critical Ratio $(\mathrm{CR}>1.96)$.

\section{Results and Discussion}

\section{Respondents' Profiles}

The respondents were female and male with the percentage of $41.3 \%$ and $58.7 \%$. As for the age of respondents, it was mostly dominated by the respondents ages between 20 to 30 years old with the percentage of $64.2 \%$, followed by respondents below the age of 20 years old with the percentage of $33.9 \%$, and the rest were above the age of 30 years old (1.9\%). Most of the respondents lived in Jakarta (50\%), followed by Bekasi (37.6\%), Tangerang (6.4\%), Bogor (5\%), and Depok (1\%). According to the whole data, only $28.9 \%$ respondents were working while the rest were not working. In addition, $80.7 \%$ respondents were students, $12.4 \%$ were officers, $2.8 \%$ were entrepreneurs, $1.8 \%$ were freelancers and the other $2.3 \%$ had different occupations. Moreover, precisely $50 \%$ of the respondents earned a monthly income below IDR 2 million, followed by $28.9 \%$ with a monthly income between IDR 2-3 million, $4.6 \%$ with monthly income between IDR 3-4 million, 3.2\% respondents with a monthly income between IDR 45 million, and $13.3 \%$ of the respondents earned more than IDR 5 million.

\section{Descriptive Analysis}

Family Influence

With the percentage of $62.8 \%$ respondents agreed that they follow their parents' example in managing their money. A total of $46.3 \%$ out of all respondents agreed that they always discussed about managing money with their parents. The next indicator also has the total of respondents that agree, which is lower than $50 \%$; $48.2 \%$ of the respondents agreed that they find it helpful when their parents control their spending. However, $60.6 \%$ respondents agree that they follow their parents' advice in saving their money. Also, $70.2 \%$ respondents agreed that they save money to help their parents lessen the spending on them. Lastly, most of respondents agreed that they were taught to save when they were kids; with the total of $82.1 \%$ respondents. 


\section{Peer Influence}

Most of the respondents (74.3\%) agreed that they know their friends have a savings account. However, only $40.8 \%$ respondents agreed that they always compared the amount of saving and spending with their friends. Then, $43.1 \%$ respondents agree that they discussed about the advantages and disadvantages of savings with their friends. Moreover, with more than $50 \%$ of all respondents, precisely $54.6 \%$ respondents agreed that they were always involved in money spending activities with their friends. But, only $45 \%$ respondents agreed that their friends and peers have been the greatest influence on how they make financial decisions. Lastly, only $42.7 \%$ respondents agreed that their friends encourage them to save.

\section{Financial Literacy}

The total amount of $63.3 \%$ respondents agreed that they understand financial terms and concept. Then, $68.8 \%$ of the respondents agreed that they understood financial instruments (savings and deposits), while those who agreed that they understood the need to invest are 56\% respondents. Next, in total there are $70.2 \%$ respondents who agreed that financial information or advice influence their saving decision to deliberately save. With the total of $65.2 \%$ respondents agreed that they can use combinations of skills, resources and knowledge to make financial decisions. However, 57.3\% respondents agreed that they can manage their money without difficulty, despite the high numbers of respondents agreed to 2 previous indicators. Lastly, $61.9 \%$ of the respondents agreed that they can make an informed and effective financial choice.

\section{Financial Attitude}

Most of the respondents (89\% out of all respondents) agreed that saving is important. They agreed that they are eager to improve their financial knowledge. In addition, total the $78.4 \%$ respondents agreed that they are interested in a saving instrument (saving and investment). Also, $62.8 \%$ of the respondents agreed that they enjoy talking about money management issues. While $58.3 \%$ of the respondents agreed that they enjoy and having interest in reading about money management.

The amount of $61.5 \%$ respondents agreed that they are confident about their money management skill and the total of $66.1 \%$ respondents agreed that they feel in control of their financial situation. Moreover, $69.3 \%$ of the respondents agreed that they feel that they could use their future income to achieve their financial goals. While $67.9 \%$ of the total respondents agree that they are capable of handling their financial future. The data shows that $61.5 \%$ of the respondents agreed that they spend less than their income. However, the data also shows that $43.6 \%$ of the respondents agreed that they are uncertain about where their money is spent. And $58.3 \%$ of the respondents agreed that they plan and implement regular saving or investment program.

\section{Saving Behaviour}

With the percentage of $88.1 \%$ out of all the respondents have a savings account and $84.9 \%$ of the respondents agreed that they save for future purposes. Moreover, a total of $81.7 \%$ of the respondents agreed that they save to achieve certain goals.

The data shows that $84.4 \%$ of the respondents compare prices before buying things in order to save and $78.4 \%$ of the respondents often considered the real necessity of item before they buy things in order to save. In addition, $65.1 \%$ of the respondents always save by following a personal planned monthly budget. Also $79.8 \%$ of the respondents agreed that they plan to reduce their expenses in order to save. With the percentage of $78.4 \%$ respondents agreed that they increase their savings when they receive a higher salary. In contrary of the number of respondents who have saving account, $51.4 \%$ of the respondents agreed that they have several types of saving (investment, savings, deposits, etc.). Moreover, $45.4 \%$ of the respondents agreed that they have emergency accounts. 


\section{Inferential Analysis}

The result of normality, validity, and reliability test shows that the data are normal, valid, and reliable. In implementing the SEM analyisis, the relation of the variables can be seen on Figure 1. The result of the goodness of fit test shows that the NFI value is 0.850 (closer to 1). The TLI value is 0.906 (higher than 0.900). The CFI value is 0.922 (higher than 0.900). Lastly, the RMSEA value is 0.064 (in between 0.05 to 0.80). These four criteria have fulfilled the requirements. According to Hair, et. al.(2010), the requirement for a model to be considered fit is to have 4 criteria passed. Therefore, it can be said that the model is a good fit model.

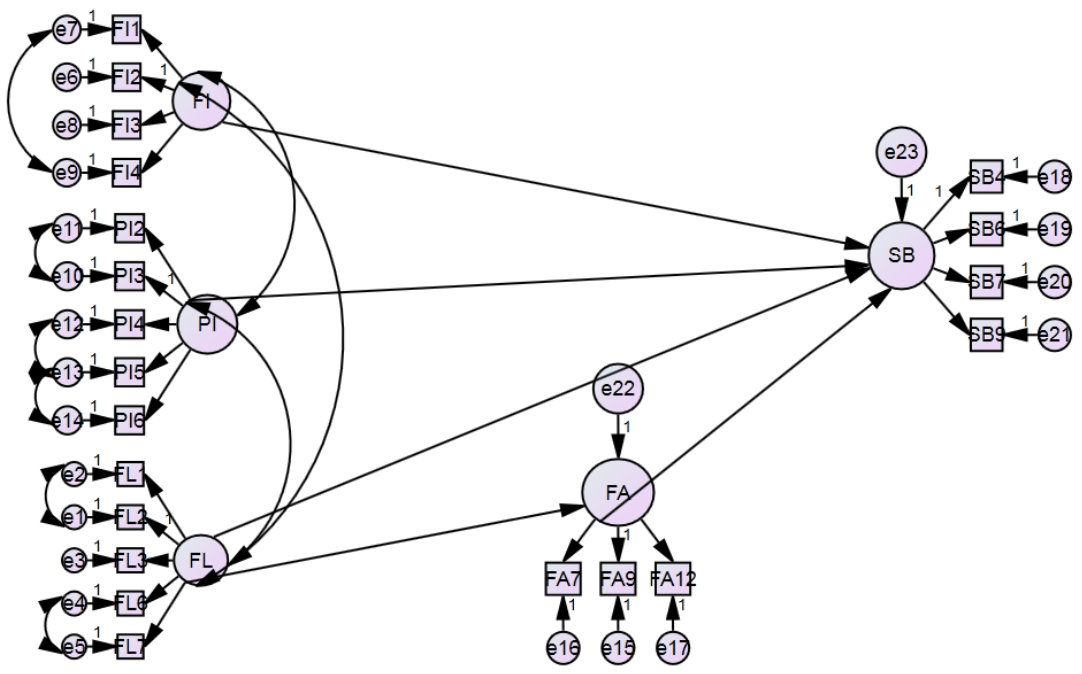

Figure 1. The Result of Structural Equation Modelling (SEM)

(Source: Statistical Software Output)

Researchers found that two out of five hypotheses are rejected because the p-value of each is 0.544 and 0.277 , which exceeded the accepted criterion ( $\mathrm{p}$-value $<0.05$ ). Those two hypotheses are H1: Family influence influences saving behaviour and H2: Peer influence influences saving behaviour. However, the other three hypotheses are accepted because the p-value of each is .***, which means it is below than 0.05 . Those three hypotheses are H3: Financial literacy influences saving behaviour; H4: Financial literacy influences financial attitude; and H5: Financial attitude influences saving behaviour.

\section{Discussions}

First, H1: Family influence influences saving behaviour is rejected, meaning that family influence does not significantly influence saving behaviour of online gamers in Greater Jakarta, Indonesia. This result is not in line with the finding of Jamal, et. al. (2015), who found that family influence greatly influences saving behaviour. Also, Jorgensen (2007) findings is not in line with this research result; he stated that one mostly learn through one's interaction with the surroundings, specifically when one spend the most of time with in the early life; specifically family. However, Williams (2010) found that some parents are not comfortable to talk to their children regarding financial matters. She mentioned that some parents prevent themselves from discussing financial matters to children because they don't want to stress the children or they felt that the children won't understand it. Hence, one of the reason family is not significant could be because of the family's feelings.

The second hypothesis (H2) is rejected, meaning that there is no significant influence of peer influence towards saving behaviour. This finding can also be found in Jorgensen (2007) study about financial literacy and financial behaviour among college students. He mentioned that one of the reasons why peer influence does not influence financial behaviour is because communication between a child and a parent is supported 
well by the recent technology which has allowed children to call and/or contact their parents more frequently. Thus, the reason of why peer influence does not significantly influence saving behaviour is because technology that developed well has distracted the social interaction and learning that one should have.

The third hypothesis is accepted, meaning that financial literacy significantly influences saving behaviour. It is supported by Thung, et. al. (2012), Jamal, et. al. (2015) and Widyastuti, Suhud, \& Sumiati (2016) who also found the significant influence of financial literacy towards saving behaviour. According to Jamal, et. al. (2015), being knowledgeable about finance or being financially literate would affect their ability in making informed financial decision. In line with the previous findings, Thung, et. al. (2012) stated that the higher one's level of financial literacy, one is more likely to save since they are able to identify the knowledge and importance of savings.

Lastly, hypothesis 4 and hypothesis 5 are accepted, meaning that financial literacy significantly influences financial attitude, and financial attitude significantly influences saving behaviour. In line with the findings from Shim, et. al. (2010), that financial knowledge or financial literacy level has an important role in influencing financial attitude and same goes for financial attitudes to financial behaviour. In addition, Shim, et. al. (2010) stated that behaviours are shaped by emotions; it supports H5 where saving behaviour is influenced by financial attitude. Moreover, Jorgensen (2007) found that having low level of financial knowledge or poorly financial literate would cause one to have negative opinions towards finances and bad financial decision making. Jorgensen (2007) stated that an increasing on financial knowledge would positively influences students' attitude and behaviour of one is related to their attitude.

\section{Conclusion and Implications}

Based on the research finding, it can be concluded that increasing of financial literacy has an important role to increase the saving behaviour of online gamers in Greater Jakarta, Indonesia. Even in other countries and other groups, family influence and peer influence significantly influence saving behaviour, it applied different to online gamers in Greater Jakarta, Indonesia.

The implication of this result is that financial institutions could involve in financial literacy campaign in order to attract the online gamers as their potential customers on saving and or investment products. Introducing financial knowledge, for example the investment instruments through an online game, will be an effective way to increase their financial literacy. It will increase their financial attitude and it will result to increase their saving bahavior. So, the financial institution will get benefit from the incresing of their saving behaviour.

For future research, researchers suggested to implement this research framework on different communities, such as influencer, blogger, youtuber, etc. This community members have a big income potential, in line with the increasing of social media usage and the increasing of digital technology usage. They are the potential saver and or investor. Therefore, knowing well their saving behaviour is very needed and interesting.

\section{References}

Achar, D. A. (2012). Saving and Investment Behaviour of Teachers - An empirical study. International Journal of Physical and Social Sciences, 2, 263-286.

Alwi, S., Hashim, I. Z. A., \& Ali, M. S. (2015). Factors Affecting Savings Habits within Millennials in Malaysia: Case Study on Students of Taylor's University. globalbizresearch. globalbizresearch.org/Malaysia_Conference/pdf/KL539.pdf

Choi, K. W. (2016). Habitus, Affordances, and Family Leisure: Cultural Reproduction through Children's Leisure Activities. Kimberley WY Choi, 18, 427-449.

Cambridge Dictionary. (2017). Cambridge Dictionary. https://dictionary.cambridge.org/dictionary/english/peer

CNN Indonesia. (2021, May 17). 5 Gaming Café di Jakarta yang Seru untuk 'Mabar'. https://www.cnnindonesia.com/gaya-hidup/20210517104918-269-643172/5-gaming-café-dijakarta-yang-seru-untuk-mabar 
Dolphin, T. (2012). Young People and Savings. London: Institute for Public Policy Research. dukcapil.kemendagri.go.id. (2021, August 1). Distribusi Penduduk Indonesia Per Juni 2021: Jabar Terbanyak, Kaltara Paling Sedikit. https://dukcapil.kemendagri.go.id/berita/baca/809/distribusipenduduk-indonesia-per-juni-2021-jabar-terbanyak-kaltara-paling-sedikit

Dwiantika, N. (Producer). (2016, November 2). Tabungan Masyarakat Masih Stagnan. Kontan. http://keuangan.kontan.co.id/news/tabungan-masyarakat-masih-stagnan

Eniola, A. A., \& Entebang, H. (2017). SME Managers and Financial Literacy. Global Business Review, $18(3), 1-18$.

Fauzi, R. F. (2020, August 10), Jumlah Gamer Indonesia Tumbuh, Masa Depan Cerah Buat Industri Esports?. https://nextren.grid.id/read/0012284184/jumlah-gamer-indonesia-tumbuh-masa-depancerah-buat-industri-esports?page $=$ all

Ferdinand, A. (2004). Strategic Selling-In Management: Sebuah Permodelan Strategi. Semarang: BP UNDIP.

Firmansyah, D. (2014). The Influence of Family Backgrounds toward Student's Saving Behavior: A Survey of College Students in Jabodetabek. International Journal of Scientific and Research Publications, 4(1), 1-6.

Gloria, G. (Producer). (2017, Februari 18). Tiga Alasan Utama Mengapa Menabung Itu Penting. Kompasiana. https://www.kompasiana.com/glorygrant/tiga-alasan-utama-mengapa-menabung-itupenting_58a841dd937a61dd3b0f80b2

Hair, J., Black, W., Babin, B., \& Anderson, R. (2010). Multivariate Data Analysis. London: PrenticeHall.

Herdjiono, I., \& Damanik, L. A. (2016). Pengaruh Financial Attitude, Financial Knowledge, Parental Income Terhadap Financial Management Behavior. Jurnal Manajemen Teori dan Terapan, 9(3), 226-241.

Jamal, A. A. A., Ramlan, W. K., Karim, M. A., Mohidin, R., \& Osman, Z. (2015). The Effects of Social Influence and Financial Literacy on Savings Behavior:A Study on Students of Higher Learning Institutions in Kota Kinabalu, Sabah. International Journal of Business and Social Science, 6(11(1)), 110-119.

Jorgensen, B. L. (2007). Financial Literacy of College Students: Parental and Peer Influences. Blacksburg: Virginia Polytechnic Institute and State University.

Kapounek, S., Korab, P., \& Deltuvaite, V. (2015). (Ir)rational households' Saving Behavior? An Empirical Investigation. Procedia Economics and Finance, 39, 625-633.

Latifa, N. E. (Producer). (2017, November 12). Karena Game Online. kompasiana. https://www.kompasiana.com/beritanendank/5a086b0cfcf6815e3c6126f3/karena-game-online

Lien, N. H., Westberg, K., Stavros, C., \& Robinson, L. J. (2017). Family Decision-making in an Emerging Market: Tensions with Tradition. Journal of Business Research, 86, 479-489.

NewZoo. (2017, June 1). The Indonesian Gamer | 2017. https://newzoo.com/insights/infographics/theindonesian-gamer-2017/

Nisaputra, R. (Producer). (2016, October 31). OJK Dorong Budaya Menabung. infobanknews. http://infobanknews.com/ojk-dorong-budaya-menabung/

Oktavira, B. A. (Producer). (2016, December). 5 Peringkat Indonesia Di Mata Dunia. CalonSH. http://www.calonsh.com/2016/11/08/5-peringkat-indonesia-di-mata-dunia

Potrich, A. C. G., Vieira, K. M., \& Mendes-Da-Silva, W. (2016). Development of a Financial Literacy Model for University Students. Management Research Review, 39(3), 356-376.

Prakasa, R. A. (Producer). (2016, August 19). Pelajar Ini Habiskan Ratusan Ribu Per Bulan Main Game Online di Warnet. BangkaPos. http://bangka.tribunnews.com/2016/08/19/pelajar-ini-habiskanratusan-ribu-per-bulan-main-game-online-di-warnet?page $=2$

Putri, S. A. A. (2017, January 9). Catat, Alasan Anda Wajib Miliki Tabungan!. https://money.kompas.com/read/2017/01/09/104917726/catat.alasan.anda.wajib.miliki.tabungan

Shim, S. Y., Barber, B. L., Card, N. A., Xiao, J. J., \& Serido, J. (2010). Financial Socialization of Firstyear College Students: The Roles of Parents, Work, and Education. Journal of Youth Adolescence, 39(12), 1457-1470.

Subhamv, \& Priya, P. S. (2016). A Study on Factors Affecting Savings Behaviour of Gen Y. Asian Journal of Research in Social Sciences and Humanities, 6, 1627-1636.

Thung, C. M., Kai, C. Y., Nie, F. S., Chiun, L. W., \& Tsen, T. C. (2012). Determinats of Saving Behaviour among The University Students in Malaysia. Petaling Jaya: Universiti Tunku Abdul Rahman, 1-109. 
Tuffour, J. K., Amoako, A. A., \& Amartey, E. O. (2020). Assessing the Effect of Financial Literacy Among Managers on the Performance of Small-Scale Enterprises. Global Business Review, 1, 118.

Widyastuti, U., Suhud, U., \& Sumiati, A. (2016). The Impact of Financial Literacy on Student Teachers' Saving Intention and Saving Behaviour. Mediterranean Journal of Social Sciences, 7(6), 41-48.

Williams, S. (2010). Parental Influence on the Financial Literacy of Their School-Aged Children: An Exploratory Study. The Journal of Undergraduate Research, 8, 23-33. 